\title{
Asuhan Kebidanan Pertumbuhan dan Perkembangan pada Balita dengan Wasting
}

\author{
Dzul Istiqomah Hasyim*, Cynthia Puspariny, Epi Susanti \\ Program Studi DIII Kebidanan, Fakultas Kesehatan, Universitas Muhammadiyah Pringsewu, Indonesia \\ *Corresponding author: dzulistiqomah10@umpri.ac.id
}

\begin{abstract}
Underweight toddlers (wasting) is a condition where toddlers suffer from nutritional disorders with a diagnosis that is enforced based on an assessment of height per body weight. This indicates a deficit or lack of proportion of body weight when compared to height in toddlers. Under-five deaths amounted to 6.6 million people, meaning that 18,000 children under five died every day, which indirectly contributed to $60 \%$ under-five mortality as the underlying causes of infectious diseases as the direct cause of death. This case study uses the SOAP (Subjective, Objective, Assessment, Planning) method of documentation. The subject of this study was a child aged 2 years old. Methods in collecting data, carried out using anamnesis, physical examination, analyzed and carried out management. The results were obtained in the subject has normal development with wasting growth. Conclusion the subject has normal development with the growth of wasting, the management of the case was appropriate theory and practice.
\end{abstract}

Keywords: toddlers, growth, wasting

\begin{abstract}
ABSTRAK
Balita kurus (wasting) adalah suatu kondisi dimana balita menderita gangguan gizi dengan diagnosis yang ditegakkan berdasarkan penilaian tinggi badan per berat badan. Hal ini menunjukkan adanya defisit atau kekurangan proporsi berat badan bila dibandingkan tinggi badan pada balita. Pada tahun 2012 kematian balita berjumlah 6,6 juta jiwa artinya 18.000 jiwa balita meninggal setiap harinya dimana secara tidak langsung wasting atau balita kurus menyumbang 60\% kematian balita sebagai underlying causes terhadap penyakit infeksi sebagai penyebab langsung kematian. Studi kasus ini dengan menggunakan pendokumentasian metode SOAP (Subjektif, Objektif, Assessment, Planning). Subjek penelitian ini adalah anak usia 2 tahun. Metode dalam pengumpulan data, dilakukan dengan menggunakan anamnesa, pemeriksaan fisik, analisis dan penatalaksanaan kasus. Hasil didapatkan anak perkembangannya normal dengan pertumbuhan wasting. Simpulan subjek perkembangannya normal dengan pertumbuhan wasting, penatalaksanaan kasus sudah sesuai teori dan praktek.
\end{abstract}

Kata kunci: anak, tumbuh kembang, wasting

\section{PENDAHULUAN}

Wasting merupakan gabungan dari istilah kurus (wasted) dan sangat kurus (severe wasted) yang didasarkan pada indeks Berat Badan menurut Panjang Badan (BB/PB) atau
Berat Badan menurut Tinggi Badan (BB/TB) dengan ambang batas (Z score) <-2 SD. Pada tahun 2012 kematian balita berjumlah 6,6 juta jiwa artinya 18.000 jiwa balita meninggal setiap harinya dimana secara tidak langsung 
wasting atau balita kurus menyumbang $60 \%$ kematian balita sebagai underlying causes terhadap penyakit infeksi sebagai penyebab langsung kematian. Tahun 2013 dari 161 juta jiwa balita di dunia menderita kelaparan dimana 51 juta jiwa balita diantaranya menderita wasting. Di negara berkembang dan miskin, persoalan nutrisi berkisar seputar kekurangan asupan sehingga menimbulkan defisiensi nutrisi seperti kekurangan energi protein, anemia, defisiensi iodium dan kekurangan mikronutrien lain (1).

World Health Organization (WHO) memperkirakan bahwa 175 juta anak di negara berkembang mengalami malnutrisi dilihat dari data berat badan menurut umur dan sekitar 230 juta mengalami stunted dilihat dari tinggi badan menurut umur. Pada tahun 2007, hampir 20 juta anak bawah lima tahun (balita) menderita malnutrisi berat akut. Menurut WHO, anak penderita gizi buruk berisiko kematian 5-20 kali lebih besar dari pada anak dengan nutrisi baik. Malnutrisi bertanggung jawab langsung dan tidak langsung terhadap $60 \%$ kematian balita, lebih dari dua pertiga kematian tersebut justru terjadi pada usia kurang dari satu tahun. Indonesia merupakan negara berkembang yang masih memiliki masalah gizi kurang yaitu wasting (1).

Berdasarkan riset daerah provinsi Lampung ditemukan prevalensi gizi kurang sebesar $17,5 \%$ dan sudah mencapai target nasional perbaikan gizi pada tahun 2015 (20\%), MDGs $(18,5 \%)$ dari 10 kabupaten/kota hanya ada 2 kabupaten yang belum mencapai target MDGs yaitu kabupaten Tanggamus dan Lampung utara (2).

Menurut Call dan Levinson, bahwa status gizi dipengaruhi oleh dua faktor yaitu konsumsi makanan dan tingkat kesehatan, kedua faktor ini adalah penyebab langsung, sedangkan penyebab tidak langsung yaitu kandungan zat gizi dalam bahan makanan, kebiasaan makan, ada tidaknya program pembelian makanan di luar keluarga, pemeliharaan kesehatan, daya beli keluarga, serta lingkungan fisik dan sosial (3).

Studi lain menjelaskan, faktor penyebab dari kejadian balita kurus (wasting) diantaranya, pemberian ASI yang tidak optimal, status ekonomi miskin dan pendidikan ibu, diare dan morbiditas saluran pernapasan, saluran sanitasi dan tempat tinggal di pedesaan terkait dengan meningkatnya kemungkinan balita kurus (wasting) di antara anak-anak kurang dari 5 tahun (4).

Gizi kurang pada balita dapat menyebabkan kecerdasan anak terganggu, menurunnya produktivitas anak serta rendahnya kemampuan kognitif dan menyebabkan terganggunya perkembangan anak sehingga bisa menyebabkan keterlambatan perkembangan (5).

Stimulasi atau kegiatan merangsang kemampuan dasar anak umur 0-6 tahun agar anak tumbuh berkembang secara optimal. Setiap anak perlu mendapatkan stimulasi rutin sedini mungkin dan terus menerus pada setiap kesempatan, stimulasi tumbuh kembang anak dilakukan oleh ibu dan ayah yang merupakan orang terdekat dengan anak, pengganti ibu/pengasuh anak, anggota keluarga lain dan kelompok masyarakat di lingkungan rumah tangga masing-masing dan dalam kehidupan sehari-hari. Kurangnya stimulasi dapat menyebabkan penyimpangan tumbuh kembang anak bahkan gangguan yang menetap. Kemampuan dasar anak yang dirangsang dengan stimulasi terarah adalah kemampuan gerak kasar, kemampuan gerak halus, kemampuan bicara dan bahasa serta kemampuan sosialisasi dan kemandirian (6).

Terkait hal di atas keterlambatan tumbuh kembang pada anak dikarenakan 
kurangnya orang tua mengenal tanda bahaya perkembangan anak, kurangnya pemeriksaan deteksi dini atau skrining perkembangan pada anak dan kurangnya keterlibatan langsung orang tua dengan anak atau stimulasi dari selain orang tua. Akan sangat berpengaruh, seorang ibu yang berpengetahuan tentang stimulasi dini dengan ibu yang berpengetahuan stimulasi dini yang rendah akan beresiko lebih besar untuk mengalami dugaan keterlambatan perkembangan (7).

Masalah yang akan terjadi tidak hanya keterlambatan perkembangan seperti yang dijelaskan di atas tetapi adapun faktor penghambat perkembangan lain terhadap balita yaitu gizi kurang, gizi kurang merupakan salah satu masalah kesehatan yang berkontribusi terhadap rendahnya kualitas Sumber Daya Manusia (SDM) di Indonesia. Asupan gizi dengan kualitas dan kuantitas yang baik sangat dibutuhkan terutama pada usia balita karena pertumbuhan dan perkembangan fisik serta kognitif sedang tumbuh dengan pesat pada tahap usia tersebut (5).

Penelitian sebelumnya yang dilakukan pada siswa PAUD di TK 'Aisyiyah Pringsewu didapatkan sebanyak 31 siswa $(60 \%)$ balita berada pada status gizi normal, sedangkan sisanya berada pada status gizi wasting 14 siswa (40\%). Secara statistik diperoleh nilai $\mathrm{OR}=22,500$ yang berarti bahwa responden yang penghasilannya kurang baik mempunyai risiko 22,5 kali untuk terjadinya wasting dibandingkan pada responden yang status ekonomi keluarganya baik (8).

Berdasarkan hasil survey yang dilakukan di Kota Batu, Kota Agung, ibu subjek mengatakan anaknya susah untuk makan, dan senang mengkonsumsi jajan serta makanan instan. Hasil pemeriksaan subjek usia 2 tahun, berat badan: $11 \mathrm{~kg}$, tinggi badan: $92 \mathrm{~cm}$, lingkar kepala: $49 \mathrm{~cm}$, LILA (Lingkar Lengan Atas): $16 \mathrm{~cm}$, dan lingkar dada: $60 \mathrm{~cm}$.

Berdasarkan pertimbangan besarnya masalah dan dampak dari pertumbuhan serta perkembangan yang kurang akibat wasting, penulis tertarik untuk membahas tentang asuhan kebidanan pada anak dengan stunting. Tujuan studi kasus ini adalah melaksanakan asuhan kebidanan pada pertumbuhan dan perkembangan anak melalui pendekatan pola pikir manajemen asuhan kebidanan Varney secara komprehensif.

\section{LAPORAN KASUS}

Pengkajian dengan metode SOAP yaitu mengkaji data subjektif yang diperoleh dari orangtua anak, dilanjutkan dengan pemeriksaan fisik, pemeriksaan pertumbuhan dan perkembangannya dengan menggunakan alat kuesioner Stimulasi, Deteksi, Intervensi Dini Tumbuh Kembang (SDIDTK). Sebelum dilakukan anamnesis pasien, orangtua pasien setuju akan pemeriksaan dan menandatangani lembar inform consent. Data subjektif didapatkan anak usia 2 tahun, jenis kelamin laki-laki. Ibu subjek menginformasikan bahwa An termasuk picky eater atau susah makan, lebih senang mengkonsumsi jajanan warung. Riwayat kehamilan anak, lahir dengan usia kehamilan 40 minggu, ditolong oleh bidan, berat badan lahir 3700 gram, ibu tidak memberikan ASI eksklusif.

Riwayat imunisasi lengkap, riwayat penyakit subjek dan keluarga tidak ada penyakit menular, menurun dan menahun seperti PMS, TBC, HIV/AIDS, HEPATITIS, DM, ASMA dan Hipertensi. Pola kebutuhan sehari-hari terkaji pola makan frekuensi makan: 2 kali/hari dengan porsi 1 piring kecil, jenis: nasi, lauk, sayur. Keluhan: anak malas makan, anaknya termasuk pemilih makanan. Pola minum frekuensi: $8 \mathrm{kali} / \mathrm{hari}$, porsi: 1 gelas, jenis: air putih, susu, minuman 
kemasan, keluhan: anaknya terkadang minum kemasan yang ada pengawet, perasa dan pemanis buatan.

Pola eliminasi tidak keluhan, pola personal hygiene subjek mandi $2 \mathrm{kali} / \mathrm{hari}$, gosok gigi $2 \mathrm{kali} / \mathrm{hari}$ dengan bantuan ganti pakaian 2 kali/hari, keramas 3 kali /minggu. Pola istirahat tidur siang \pm 3 jam, tidur malam \pm 11 jam. Ibu mengatakan anaknya rajin belajar berbicara dan berhitung dengan ayahnya. Saat ini anaknya aktif bermain dengan kakaknya. Subjek hanya bermain di rumah dan lingkungan rumah saja.

Pemeriksaan objektif didapatkan keadaan umum baik, pernafasan $24 \mathrm{kali} / \mathrm{menit}$, frekuensi jantung $93 \mathrm{kali} / \mathrm{menit}$, suhu $36^{\circ} \mathrm{C}$. Pemeriksaan antropometri dilaporkan berat badan $11 \mathrm{~kg}$, tinggi badan $92 \mathrm{~cm}$, lingkar kepala $49 \mathrm{~cm}$, LILA $16 \mathrm{~cm}$, lingkar dada 60 $\mathrm{cm}$. Pemeriksaan head to toe didapatkan semua dalam keadaan normal dan baik. Hasil Kuesioner Pra Skrining Perkembangan (KPSP) terdeteksi normal, dengan menggunakan form didapatkan hasil jawaban "Ya"=10 berarti sesuai umur. Pemeriksaan TDD (Tes Daya Dengar): Jumlah jawaban "Tidak" $=0$, maka analisa subjek tidak mengalami gangguan pendengaran. Pemeriksaan TDL (Tes Daya Lihat): Jumlah jawaban "Tidak" $=0$, maka analisa subjek tidak mengalami gangguan penglihatan. Pada pemeriksaan perkembangan mental emosional, semua jawaban "tidak", maka analisa subjek tidak mengalami masalah pada perkembangan mental dan emosional. Pada pemeriksaan Gangguan Pemusatan Perhatian dan Hiperaktivitas (GPPH), tidak ditemukan gangguan pemusatan perhatian dan subjek tidak termasuk kedalam anak dengan hiperaktif.

Berdasarkan hasil pemeriksaan dan data subjektif serta objektif ditegakan assessment yaitu subjek usia 2 tahun dengan perkembangan normal sesuai usia, tetapi pertumbuhan terdapat masalah, yaitu "wasting"/kurus. Penatalaksanaan yang dilakukan adalah memberikan pendidikan kesehatan kepada orang tua subjek mengenai kondisi anaknya, diantaranya membiasakan anak makan sesuai dengan jadwalnya dan porsi seimbang, menjelaskan pada ibu agar memantau pola makan anak dan menambah asupan makanan yang tinggi karbohidrat, protein hewani, nabati, sayuran dan mineral bagi anaknya. Menganjurkan kepada ibu untuk terus rajin memantau perkembangan dan pertumbuhan anaknya di posyandu setiap bulan. Membantu ibu membuat jadwal makan agar rutin makan dan mengurangi jajanan.

\section{PEMBAHASAN}

Balita kurus adalah suatu kondisi dimana balita menderita gangguan gizi dengan diagnosis yang ditegakkan berdasarkan penilaian tinggi badan per berat badan. Hal ini menunjukkan adanya defisit atau kekurangan proporsi berat badan bila dibandingkan tinggi badan pada balita (4). Saat ini Indonesia termasuk salah satu dari 117 negara yang mempunyai tiga masalah gizi tinggi pada balita yaitu stunting, wasting dan overweight yang dilaporkan di dalam Global Nutrition Report (GNR) 2014 Nutrition Country Profile Indonesia. Prevalensi ketiga masalah gizi tersebut yaitu stunting $37,2 \%$, wasting $12,1 \%$ dan overweight $11,9 \%$ (9).

Menurut data Riset Kesehatan Dasar (Riskesdas) tahun 2010 didapatkan balita dengan gizi kurus (wasting) sebesar 7,3\%, dan hasil Riskesdas 2013 yang pada balita 0-5 tahunan oleh Kementerian Kesehatan Republik Indonesia, prevalensi balita 0-5 tahun yang mengalami masalah gizi di Indonesia $(2,10)$.

Dari prevalensi total sebesar $17,9 \%$, balita 0-5 tahun yang menderita gizi balita 
kurus (wasting) sebesar 13\%, dan sebesar 4,9\% balita menderita gizi buruk, namun prevalensi gizi balita kurus (wasting) dari tahun 2007 hingga 2010 tidak terjadi penurunan, tetap di angka $13 \%$.

Hasil Riskesdas pada tahun 2010 menyebutkan bahwa prevalensi balita gizi balita kurus (wasting) pada balita laki-laki lebih besar dibandingkan balita perempuan. Didapatkan persentase menurut Riskesdas 2010 gizi balita kurus (wasting) sebesar 7,3\%, dan tahun 2013 sebesar 7,7\% (10). Data yang diperoleh dari dinas kesehatan Provinsi Lampung (2010) memperlihatkan prevalensi gizi balita kurus (Wasting) pada balita 0-5 tahun di Lampung terus menurun dari $9,7 \%$ di tahun 2013 menjadi 4,9\% di tahun 2014.

Keterlambatan pertumbuhan dan perkembangan merupakan penyebab dari terganggunya kecerdasaan anak, menurunnya produktivitas anak serta rendahnya kemampuan kognitif. Kurangnya stimulasi akan mengakibatkan jaringan otak akan mengecil sehingga fungsi otak akan menurun. Tumbuh kembang anak mulai dari konsepsi sampai dewasa dipengaruhi banyak faktor. Faktor-faktor tersebut adalah faktor genetik dan faktor lingkungan bio-fisiko-psikososial, yang bisa menghambat atau mengoptimalkan tumbuh kembang anak.

Berdasarkan penelitian yang dilakukan dzul istiqomah di TK PAUD surya ceria Pringsewu pada tahun 2017 menjelaskan bahwa sebagian besar $(60 \%)$ balita berada pada status gizi normal, sedangkan sisanya berada pada status gizi wasting (40\%). Status ekonomi keluarganya baik, sebesar 3,28\% diantaranya ada kejadian wastin, sedangkan responden yang status ekonomi keluarganya kurang mengalami kejadian wasting (42,9\%) dan sebanyak $57,1 \%$ responden normal. Hasil uji statistik diperoleh nilai $\mathrm{p}$ value $=0,002$ sehingga $\mathrm{p} \leq 0,05$, maka $\mathrm{H} 0$ ditolak dan $\mathrm{Ha}$ diterima. Hal ini berarti dari hasil penelitian menunjukan adanya hubungan status ekonomi dengan kejadian balita kurus (wasting) di PAUD Surya Ceria Pringsewu (8).

Berat badan tidak sesuai dengan umur anak setelah dilakukan penyesuaian menggunakan standar berat badan dan tinggi badan, subjek terdeteksi kurus, penatalaksanaan memberitahu ibu untuk memberikan makanan seimbang, pemberian makanan tambahan dan disarankan untuk terus melakukan penilaian terhadap berat badan.

\section{SIMPULAN}

Subjek termasuk kategori kurus, perkembangannya normal dengan pertumbuhan wasting dan penatalaksanaan kasus sudah sesuai teori dan praktek.

\section{KONFLIK KEPENTINGAN}

Studi kasus ini tidak memiliki konflik kepentingan, dan tidak ada afiliasi atau koneksi dengan entitas atau organisasi apa pun, yang dapat menimbulkan pertanyaan bias dalam diskusi dan kesimpulan naskah.

\section{UCAPAN TERIMA KASIH}

Ucapan terima kasih kepada Universitas Muhammadiyah Pringsewu yang telah memberikan wadah dan memfasilitasi dalam penelitian dosen

\section{REFERENSI}

1. Kementerian Kesehatan. Asuhan Kebidanan Neonatus, Bayi, Balita dan Anak Pra Sekolah. Jakarta: Kementerian Kesehatan Republik Indonesia; 2013.

2. Kementerian Kesehatan Republik Indonesia. Riset Kesehatan Dasar 2013. Badan Penelitian dan Pengembangan Kesehatan. Jakarta: Kementerian Kesehatan Republik 
Indonesia; 2013.

3. Supariasa. Pendidikan dan Konsultasi Gizi. Jakarta: EGC; 2012.

4. Derso T, Abera Z, Tariku A. Magnitude and associated factors of anemia among pregnant women in Dera District: a cross-sectional study in northwest Ethiopia. BMC Res Notes. 2017 Dec;10(1):359.

5. Yulistianingsih A, Kartini A. Hubungan Asupan Isoflavon dengan Kejadian Sindroma Metabolik pada Wanita Menopause. J Nutr Coll. 2014 Oct;3(4):903-10.

6. Kementerian Kesehatan. Pedoman pelaksanaan stimulasi, deteksi dan intervensi dini tumbuh kembang anak ditingkat pelayanan kesehatan dasar. Jakarta: Departemen Kesehatan; 2009.

7. Handini D, Ichsan B, Nirlawati DD. Hubungan Tingkat Pendapatan Keluarga dengan Status Gizi Balita di Wilayah Kerja Puskesmas
Kalijambe. Biomedika. 2013 Aug;5(2).

8. Istiqomah D. Hubungan Status Ekonomi Dengan Kejadian Balita Kurus (Wasting) Di Paud Surya Ceria Pringsewu. J Ilm Kesehat. 2017;6(2):20-4.

9. International Food Policy Research Institute (IFPRI). The Global Nutrition Report 2014: Actions and Accountability to Accelerate the World's Progress on Nutrition. 2015 Apr.

10. Kementerian Kesehatan Republik Indonesia. Riset Kesehatan Dasar; Badan Penelitian dan Pengembangan Kesehatan Kementerian Kesehatan RI Tahun 2010. Laporan Nasional 2010. Jakarta; 2010.

11. Winarsih. Pengantar Ilmu Gizi dalam Kebidanan. Jakarta: Salemba Medika; 2017. 